\title{
Body Structure and Names of Disease in the Dictionary by Mahmut Kashkari and Their Relationship with Modern Kyrgyz Language
}

\author{
Sara Davlatova1, Nurzhamal Mapaeva², Kanyshai Chotikeeva1, Nazgul Tahirova1, \\ Seil Turgunbaeva', Zhannat Dzhumaeva ${ }^{3}$, Uyalkhan Kamardinova ${ }^{2}$, Zhypargul Abdullaeva ${ }^{*}$ (I) \\ ${ }^{1}$ Department of Kyrgyz Language and Literature, Medical College, Osh State University, Osh, Kyrgyzstan \\ ${ }^{2}$ Department of Kyrgyz Language Sciences, Osh State University, Osh, Kyrgyzstan \\ ${ }^{3}$ Department of Kyrgyz Language and Literature, Humanitarian Pedagogical Institute, Osh, Kyrgyzstan \\ ${ }^{4}$ Science and Research Department, Osh State University, Osh, Kyrgyzstan \\ Email: *jypar.science@oshsu.kg
}

How to cite this paper: Davlatova, S., Mapaeva, N., Chotikeeva, K., Tahirova, N., Turgunbaeva, S., Dzhumaeva, Z., Kamardinova, U., \& Abdullaeva, Z. (2021). Body Structure and Names of Disease in the Dictionary by Mahmut Kashkari and Their Relationship with Modern Kyrgyz Language. Open Journal of Modern Linguistics, 11, 201-211.

https://doi.org/10.4236/ojml.2021.112016

Received: February 25, 2021

Accepted: April 18, 2021

Published: April 21, 2021

Copyright ( 2021 by author(s) and Scientific Research Publishing Inc. This work is licensed under the Creative Commons Attribution International License (CC BY 4.0).

http://creativecommons.org/licenses/by/4.0/

(c) (i) Open Access

\begin{abstract}
The article is relevant in determining the role of modern Kyrgyz language as one of the ancient Turkic languages. The purpose of this article is to determine the level of words used in the modern Kyrgyz language described in the dictionary "Divanu lugati t-turk" by Mahmut Kashkari, including names of diseases, and linguistic phenomena in the transformation of words. Research objects are translated words in the M. Kashkari's dictionary. The study is based on the historical-comparative method. As a result of this study, it was found that the names of physical structures and diseases in the dictionary by M. Kashkari in the modern Kyrgyz language are subjected to phonetic changes (őt - gallbladder, kőz - eye, head - head, eyelash - eyelash, irin - pus, etc.), but some of them are subjected to phonetic changes (buğın - joint, bőgőn - lump, ažaq - foot, foot, ämik - breast, ärnäk - toe, sigil - wart, etc.) and some words have other names that are not used at all (tılaq - female genitalia, ožluq - bone marrow, kősri - chest, bağıriaq - rash, etc.).
\end{abstract}

\section{Keywords}

Vocabulary, Body Structure, Names, Related Languages, Phonetic Changes,

Vowels, Consonants, Long Vowels, Level of Usage, Ancient Language,

Diphthongization, Linguistic Dialect, Similarities, Differences

\section{Introduction}

The article is relevant in determining the role of modern Kyrgyz language as one 
of the ancient Turkic languages. The purpose of this article is to determine the level of words used in the modern Kyrgyz language, described in the dictionary "Divanu lugati t-turk" by Mahmut Kashkari (Usmambetov, 2016; Isabekova, 2017), to determine the level of linguistic phenomena in the transformation of words, to compare changes with related languages (Davlatova, 2019).

This study is based on the historical-comparative method, where study objects are translated words from the following dictionaries: 1) Mahmut Kashkari. Divanu lugati-t turk. Turkic language vocabulary, translated by Abduvaliev et al., Bishkek: Biyiktik, 2013a, 512 pages; 2) Mahmut Kashkari. Divanu lugati-t turk. Turkic Dictionary of languages, translated by Abduvaliev et al., Bishkek: Biyiktik, 2013b, 304 pages; 3) Mahmoud Kashgari. Dictionary of Turkic languages, translated by Tokoev, T. and Koshmokov, K., Bishkek: Avrasya Press, 2011, 906 pages.

The dictionary "Divanu lugati t-turk" written by the linguist-encyclopedist Mahmut Kashkari in middle centuries which is famous until today, is invaluable linguistic and historical monument of all Turkic language people. Scientist Malov noted about the Dictionary by Mahmut Kashkari: "a wonderful philological combination" (Malov, 1951). This valuable dictionary is an important source in the study of Turkic languages, including the Kyrgyz language. Linguist-scientist B. Oruzbaeva noted in her article named "Dictionary by Mahmud Kashgari as a source for study the Kyrgyz language lexicon in historical plan": "Divan by M. Kashgari contains valuable material for differential, deep study of the Kyrgyz language history, for establishing of its some specific regulations, formation of grammatical and lexical-semantic peculiarities" (Oruzbaeva, 2011; Isaeva, 2019).

Therefore, the dictionary plays an important role in historical study of the modern Kyrgyz language lexicon. This article collected words related to the body structure described in the dictionary, and explanations based on comparison with words given in the modern Kyrgyz language. In addition, article is considering similarities and differences in appearance of certain words in other related Turkic languages (Johanson, 2020). It was found that most of words related to the body structure in this work used in the modern Kyrgyz language; some of them were changed phonetically; a few words were not used in the modern Kyrgyz lexicon, and had other meanings.

We used the comparative-historical method in this article, which is determining similarity of languages and study of the diachronic development in related languages. The article uses a comparative-historical method of research, which includes the following methods: 1) external reconstruction based on common words finding, morphemes in the cognate language and revealing their phonetic changes in the ancestral language; 2) internal reconstruction characterizing by discovery of phenomena and interactions in the language system, which were evidence of certain elements characteristic of the earliest stages in the language history.

In connection with the dictionary "Divanu lugati t-turk" by the great linguist Mahmut Kashkari, the famous scholar from Azerbaijan, Rahimov Arif Rahim 
oglu conducted a special study, and compared materials of the dictionary with the lexicon of the modern Azerbaijan language. He examined features of the words used in Mahmut Kashkari's dictionary in the modern Azerbaijan language and its dialects, and divided them into three groups:

1) Modern Azerbaijan language in the lexicon of "Divan" and words used without change in dialects;

2) Phono-morphological changes in the words "Divan" in modern Azerbaijan language and dialects;

3) The use of the words "Divan" in modern Azerbaijan languages and dialects through phonetic changes (Ragimov, 1985).

Additionally, this article is collecting words related to body structure in the dictionary, and compares them with modern Kyrgyz words, sometimes considering similarities and differences with their appearance in other related languages, and dividing into following types:

1) Body structure names used in the modern Kyrgyz language without changing their appearance in the dictionary;

2) Body structure names used in modern Kyrgyz language with phonetic changes;

3) Body structure names found in the dictionary of M. Kashkari, but not used in the modern Kyrgyz language, and have other names.

The following examples related to body names used in the modern Kyrgyz language, and can be given without changing their appearance in the dictionary:

öt - gallbladder (Abduvaliev et al., 2013a).

kőz - eye (Abduvaliev et al., 2013a). Karacalpak: eye; Azerbaijan: göz; Kazakh: köz; Turkmen: eye contact.

jüz - face, face (Abduvaliev et al., 2013a). This word is also used in related languages: Karacalpak language: $Y^{3}$, бәт; Azerbaijan: üz.

ear - qulaq äşitsä kőnül bilir kőz kőrsä üžik kälir (Abduvaliev et al., 2013a). Karacalpak: қулақ; Azerbaijan: qulaq.

baş - head: anın başi ağırdı - he has headache (Abduvaliev et al., 2013a). Karacalpak: баш, каллаж Azerbaijan: baş, Tatar: баш; Turkmen: кelle; Uzbek: вosh;

eyelashes - Азерб. kirpik, Tatar: керфек; Kazakh: кірпік; Uzbek: kirpik;

til - тил(Abduvaliev et al., 2013a). Karacalpak: тил, нутуқ; Azerbaijan: dil;

biläk - wrist (Abduvaliev et al., 2013a). Turkmen: bilek; Uzbek: bilak; Kazakh: білек; Tatar: беләк; Azerbaijan: bilək.

qarın - stomach (Abduvaliev et al., 2013a); Karacalpak: қарин; Azerbaijan: qarın;

arqa - arch, back (Abduvaliev et al., 2013a). Azerbaijan: arxa; Kazakh: арка; Tatar: apx.

içägü - intestine (internal organs inside the ribs) (Abduvaliev et al., 2013a);

qoltıq - armpit (Abduvaliev et al., 2013a). In related languages: Azerbaijan: qoltuq; Tatar: култык, Kazakh: қолтық; Turkmen: goltuk; Uzbek: qo'ltiq.

biqin - bykyn (Abduvaliev et al., 2013a). In related languages: Uzbek: bykyn; Kazakh: бықын; Tatar: быкын; Azerbaijan: быкын, Turkmen: быкуn. 
őpkä - lungs (Abduvaliev et al., 2013a). Azerbaijan: lungs; Kazakh: lung; Turkmen: öýken; Uzbek: o’pka; Tatar: үпкә.

Қареқ - eye pupil (Abduvaliev et al., 2013a). Uzbek: ko’z qorachig'I; Kazakh: көз қарашығы.

It is clear from the above examples that most of the words used in the ancient Kyrgyz language in their ancient form have undergone only phonetic changes in related languages (vowels, consonants). Phonetic realization of a phonological elements in the Kyrgyz language vary based on range of factors, such as elements position, speech rate, and style (McCollum, 2020). Consonant sounds at the beginning of a word, and at the end of a word should be analyzed taking into account their sonorousness, deafness and sonority (Koshueva et al., 2020). The Kyrgyz language phonetics is characterized by 8 short, 6 long phonemes, primary and secondary length long vowels; the law of vowel harmonization is depending on the sound quality, place of formation, tongue position, labialization, indicating a phonetic, grammatical peculiarity of the Kyrgyz language in comparison with other Turkic languages (Musaev, 2016).

öZ - core (part of the body belonging to the esophagus): őzüm ağrıdı - pain in the core (Malov, 1951). This word in the modern Kyrgyz dictionary means internal passages, or the inner part in abdomen. For example, kumys burned the esophagus (Abduvaliev et al, 2011). It is shown that in the modern Kyrgyz language, words are formed by continuation.

The dictionary also includes the following words related to body structure:

teeth - human teeth; ол тиш сығздады; he cleaned his teeth with toothpick (Tokoev \& Koshmokov, 2011).

hand - hand, wrist; ол қолын сытғады; he squeezed his hand and rolled up his sleeves (Tokoev \& Koshmokov, 2011).

head - head (Tokoev \& Koshmokov, 2011).

eyebrow - eyebrow (Tokoev \& Koshmokov, 2011).

ear - ear: қулақым сыңылады; my ear is ringing (Tokoev \& Koshmokov, 2011).

blood - blood (Tokoev \& Koshmokov, 2011).

old - wrist, old bone, distance from elbow to wrist (Tokoev \& Koshmokov, 2011).

\section{Phonetically Altered Words}

ağı - a person's mouth: ağ1z jäsä kőz ujažur, the mouth, the eye is ashamed (Abduvaliev et al., 2013a); This word is spoken in the modern Kyrgyz language. Most of words containing long sound oo are involving pronunciation with short vowels in ancient Turkic inscriptions. The turbulent sound $\Gamma$ between the two vowels is softened, passed to the diphthong $w$, and then a long vowel is formed: a $+\Gamma+$ d > ow > oo. Occurs in other Turkic languages these words are following: Turkic: agyz; Uzbek: mouth; Kazakh: mouth; Karacalpak: авиз, егиз.

Azığ - jaw (Abduvaliev et al., 2013a). In this example, vowels and consonants 
formed from a sequence by long vowels diphthongization: $\mathrm{b}+\mathrm{r}>\mathrm{w}>\mathrm{yy}$.

The following examples shown in the dictionary of M. Kashkari, and pronounced in the modern Kyrgyz language with a long vowel sound:

buğın - a wrist of hands (Abduvaliev et al., 2013a). In the related languages: Turkmen: bogun; Uzbek: бугим, Kazakh: буын.

bagirsuq - liver (intestine-liver) (Nadelyaev et al., 1969); Turkmen. Bagyr; Kazakh: liver.

ažaq - foot (Abduvaliev et al., 2013a). Here sound 3 transition to the sound $\check{и}$ in modern Kyrgyz, it is pronounced as ayak. The variant ajaq was also used in the ancient Turkic language. The word has the following names in other Turkic languages: Kazakh: aяқ; Turkmen: aýak, Karacalpak: пут, aяқ.

ägin - shoulder (Abduvaliev et al., 2013a). In this example, the middle $r$ sound and $\breve{и}$ sound are used interchangeably, and in modern Kyrgyz language means shoulders. In other related languages, it has the following names: Karakalpak: йәлкә; Uzbek: yelka, Turkmen: egin; Kazakh: иық; Azerbaijan: çiyin. M. Kashkari's dictionary also contains the variant uşun which means shoulder (Abduvaliev et al., 2013a), and which is not used in the modern Kyrgyz language.

ämik - breast (Abduvaliev et al., 2013a). In this example, the phenomenon of epenthesis took place. In particular, in the modern Kyrgyz language it is pronounced with the addition of the sound $ч$. This also applies to other related languages: Uzbek: эмчак, Kazakh: емшек, Turkmen: emzik, emjek.

änäk - chin (the junction between jaws) (Abduvaliev et al., 2013a). Due to the correspondence of the sounds $\Gamma / / H / / \breve{M}$ in the Turkic languages, it became a long-lasting sound from the form of $н$ between two vowels. In particular, the following phonetic exchanges are organized: $э+$ ң $+э<$ эңэ < ээ. In modern Turkmen, it is pronounced in the form эңек. Uyghur: иңек, Uzbek: ийәк (ияк); Bashkir: эйэк.

ärnäk is also used as a finger, ärnak: bäş ärnak tüz ärmäs - five fingers (hands) are not the same (Abduvaliev et al., 2013a). In the modern Kyrgyz language, the sound $b$ is added and the sound $m$ is used instead of the previous sound, and the process of sound exchange is organized. In ancient times, vowels were also refined. The combination of the sound $b$ in this word also applies to the Uzbek, Kazakh and Turkmen languages. The fact that the vowel is pronounced as $\mathrm{m}$ can be seen in the following example: turnaq - nail: ätli turnaqlı äžirmäs - the nail is inseparable from the muscle (Abduvaliev et al., 2013a). In the Kyrgyz language southern dialect, the word is called as тырнак. In related languages, it is pronounced with the use of $\mathrm{n}$ instead of $\eta$ : Azerbaijan: dyrnak; Kazakh: nails, Turkemen: dyrnak.

çıçalaq - little finger (Abduvaliev et al., 2013a). The ancient form is used in the southern dialect but is pronounced with the sound $H$. It is possible that there were instances in the ancient form. Uzbek жимжилок, Kazakh: shynashak; Turkmen: külbike; Bashkir: сәтәкәй.

tobıq - ankle: tobıq sőnük - ankle bone (Abduvaliev et al., 2013a). In pronunciation of this word there is a consonant, which is a regular phenomenon in the 
Kyrgyz language, there is a vowel change, the vowel $\sigma$ is replaced with vowel $M$, and the consonantal vowel is pronounced as vowel.

qavuq - urinary bladder (Abduvaliev et al., 2013a). In dialect this word pronounced as куук. In its ancient form, it became a two-vowel long sound $y y$, and a silent diphthong word, and then a long poisonous vowel. In the "Dictionary of Ancient Turkic Languages" it is also given as "qavuq - urinary bladder".

burun - nose (Abduvaliev et al., 2013a). It is pronounced in the modern Kyrgyz language, where has undergone a phonetic change, i.e., the sound $b$ is replaced by the sound $\mathrm{m}$. It is found in related languages as follows: Turkemen: burun; Kazakh: мұрын; Uzbek: nose: Karakalpak: бурун.

tamğaq - throat, larynx (Abduvaliev et al., 2013a). Here sound $\Gamma$ is not pronounced. This phenomenon occurs in most words in the modern Kyrgyz language. It is also known that some Turkic languages have different names: Uzbek: томок, халқум; Kazakh: жұтқыншақ; Turkmen: bokurdak.

çübäk - pig, genitals of children (Abduvaliev et al., 2013a).

jilik - bone (Abduvaliev et al., 2013a). In related languages: Azerbaijani. bone marrow; Kazakh: bone marrow; Turkmen: iilik. In modern Kyrgyz, the sound й is replaced by the sound $ж$.

сөңүк - bone (Tokoev \& Koshmokov, 2011). The second option: bone (Tokoev \& Koshmokov, 2011). Uzbek: suyak; Turkmen: süňk; Tatar: сөяк; Azerbaijan: sümük; Kazakh: сүйек.

çär - чел, чер: közi çärli - a person who has eyes and does not like during the day (Abduvaliev et al., 2013a);

çıçamuq - without a name (finger) (Abduvaliev et al., 2013a); kuduchak kuymulchak (Tokoev \& Koshmokov, 2011);

burun - nose [5397]. It is pronounced in the modern Kyrgyz language, which has undergone a phonetic change, i.e., the sound $\mathrm{b}$ is replaced by the sound $\mathrm{m}$.

ağruğ - neck: ağruğ sőnüki - neck bone (Abduvaliev et al., 2013a). In related languages: Azerbaijan: körpücük sümüyü; Kazakh: көмей; Tatar: яка сөяге; Turkmen: ýakasy; Uzbek: bo'yin suyagi; Kazakh: жақ сүйек

йүрак - heart (Abduvaliev et al., 2013a). The ancient form of this word is preserved only in the Kazakh: жүрек; Azerbaijan: ürək; Tatar: йөрәк; Turkmen: ýürek; Uzbek: yurak.

йүлүн - spinal cord (Abduvaliev et al., 2013a). Uzbek: orqa miya; Turkmen: oňurga ýiligi; Tatar: умыртка баганасы; Kazakh: жұлын; Azerbaijan: onurğa beyni.

ağruğ - limb: ağruğ sőๆüki - limb bone [5124]. In related languages: Azerbaijani. clavicle, Kazakh: larynx; Turkmen: yakasy; Uzbek: neck bone; Kazakh: jaw bone.

мең - brain: Azerbaijan: beyin; Uzbek: miya; Tatar: ми, Turkmen: beýni; Uzbek: miya.

\section{Phonetically Changed Words}

Examples of words found in M. Kashkari's dictionary, but not used in the mod- 
ern Kyrgyz language, have other names:

tulun - forehead, (Abduvaliev et al., 2013a). Turkmen. maňlaý; alyn; Uzbek: maňlaý; alyn; Kazakh: мандай. In the Kyrgyz language, there is also same variant of the word forehead.

talaq - spleen (dial.kok tal) (Abduvaliev et al., 2013a). Kaz. spleen, uzb. taloq, azerb. spleen, Turkmen: spleen. Its ancient appearance is saved in the modern Uzbek, Azerbaijan and Turkmen languages.

kősri - chest (Abduvaliev et al., 2013a). Turkmen: döş; kükrek; Uzbek: тy̆ш; Kazakh: төсю

ovruğ - a joint of the bone, also called ogruğ (Abduvaliev et al., 2013a).

aja - hand (Abduvaliev et al., 2013a). In related languages: Kazakh: алақан; Uzbek: кафт, Turkmen: aýa. The ancient form of the word is preserved only in the Turkmen language.

ožluq - bone marrow. Thick side of the forearm (Abduvaliev et al., 2013a).

bőksäk - the upper part of the chest, neck (Abduvaliev et al., 2013a);

saqaq - chin, sagak: saqaq ohşar saqal pıçar - to play with your beard, to cut your chin (to play with your beard, to cut your chin) (Abduvaliev et al., 2013b). Turkmen. eňek, Kazakh: chin, chin. chin, chin, k. stay. chin, head. eyek, tat. chin, uig. chin. He explained the word "saga" in the "Dictionary of the Kyrgyz language" as follows: "Your saga is like a white apple, your throat is as white as a pearl” (Abduvaliev et al., 2013b).

älik - hand: on älik - right hand (Abduvaliev et al., 2013a). This word in modern Kyrgyz language means respond to greetings. In the "Kyrgyz-Russian dictionary" by K.K. Yudahin it is given as follows: alik ar, answer to greeting (in a Muslim): alik al answer to greeting (Yudakhin,, 1985). In related languages: Kazakh: signature, Turkmen. elin, gol, Uzbek: қўл, hand. The Turkmen word is elin is also used and has an analogy with its ancient appearance.

oğulçuq - the uterus of women (Abduvaliev et al., 2013a). In the ancient Turkic language oğul. For this reason, the organ in which the child is being inside called oğulçuq.

änüç - the eye retina (Abduvaliev et al., 2013a). This word does not occur in the modern Kyrgyz language.

tassu - hip (Abduvaliev et al., 2013a); yaya is the hip, the forearm is human (Yudahin, 1985).

başğaq - the place where the pelvis joins the pelvis (Abduvaliev et al., 2013a);

The shoulder is the back, the backbone: if the back is dirty, the wind is dirty, if the back is sick, people start laughing (Tokoev \& Koshmokov, 2011);

ovrug - the place where the spine attaches to the neck (Abduvaliev et al., 2013a);

argan - finger (Tokoev \& Koshmokov, 2011);

арңак - finger, i.e., suk, hungry finger, because it touches the first food (Tokoev \& Koshmokov, 2011);

yin - the human body (Tokoev \& Koshmokov, 2011); 
(қ). байнақ - something in the stomach and intestines (Tokoev \& Koshmokov, 2011);

куруғсақ - stomach (Tokoev \& Koshmokov, 2011);

қуң эт - muscular meat (Tokoev \& Koshmokov, 2011);

сарқыйық - intestine, esophagus (Tokoev \& Koshmokov, 2011);

бүкүр - kidney: he bent it - he hit it on the kidney (Tokoev \& Koshmokov, 2011);

мун тағ - a wisdom tooth: a thousand teeth - a wisdom tooth came out (Tokoev \& Koshmokov, 2011);

қонрағу - a bone at the base of the ear (Tokoev \& Koshmokov, 2011);

сыңыр: tendon: meat is tendon - meat is tendon (Tokoev \& Koshmokov, 2011);

(қ) йаңақ cheek - the bone of the jaw, which has teeth on both sides (Tokoev \& Koshmokov, 2011);

тулуң - the head, the distance between the eyes and the ears (Tokoev \& Koshmokov, 2011);

йүң - glandular, glandular flesh attached to the liver (Tokoev \& Koshmokov, 2011);

The word disease has several synonymous names in M. Kashkari's dictionary:

ig - is a disease (Abduvaliev et al., 2013a). Kazakh, disease; azerb. disease, uzbek, disease, genus. sick, tatar, illness;

ağrı̆̆ - pain (Abduvaliev et al., 2013a). Azerbaijan, disease, rust. sick, uzb. disease, goose. disease, turkm. sick;

käm - illness, disease (Abduvaliev et al., 2013a);

sőgäl - sickness (Abduvaliev et al., 2013a).

\section{Examples of Disease Names Used in Ancient Words}

Disease names in the dictionary were also grouped, researched for their place in modern Kyrgyz vocabulary, and divided into groups:

älik - hand: on älik - right hand (Abduvaliev et al., 2013a). This word in modern Kyrgyz means to respond to greetings as an Arabic word. In the "Kyrgyz-Russian dictionary" of K.K. Yudahin it is given as follows: alik ar. answer to greeting (in a Muslim): alik al answer to greeting (Yudakhin,, 1985). In related languages: Kazakh: signature, Turkmen. elin, gol, Uzbek: hand. The Turkmen version of the word elin is also used and has an analogy with its ancient appearance.

son - the uterus of women (Abduvaliev et al., 2013a). In the ancient Turkic language, it is said that a child is a son. For this reason, the organ in which the child lies may be called oğulçuq.

irin - pus. In related languages it has the following name: kazakh. pus, rust. male, Turkmen: iriň; Uzbek: yiring, Azerbaijan: pus. The ancient form of the word is preserved in the Kyrgyz, Kazakh and Turkmen languages.

qart - hardening of wound (Abduvaliev et al., 2013a). 
ala - ala (illness) (Abduvaliev et al., 2013a). Kazakh: алапес; Turkemrn: heýwere; Uzbek: moxov; Tatar: мaxay; Azerbaijan: cüzam. The second variant of the name of this disease was also used: anutı - leprosy (Abduvaliev et al., 2013a), which is a skin disease characterized by appearance of white spots on human skin. The spots join together and increase in size. Where there is a spot, the hair turns white. Ala does not affect the general condition of the body, but only as a cosmetic defect.

q1ziamuq - rubella (Abduvaliev et al., 2013a). Azerbaijan: q1zılca; Turkmen: gyzamyk; Tatar: кызамык; Uzbek: qizamiq, Kazakh: қызылша. It is an infectious disease of children with small red spots on the body, fever, inflammation around the eyes, inside the mouth and respiratory tract.

boqoq - a type of gland located between the muscle and the skin on both sides of the throat. It is an inherited disease, in progresses, patient may lose the ability to see the chest (Abduvaliev et al., 2013a).

\section{Names of Diseases with Phonetic Changes}

tutuğ - seizure (demonic disease) (Abduvaliev et al., 2013a). Tatar: тотылу; Каzakh: тұтылу, tutilish; Azerbaijan: tutulma.

çäkäk - smallpox (smallpox) (Abduvaliev et al., 2013a). Tatar: жил чәчәге;

Uzbek: suvchechak, Turkmen: towuk zäheri; Kazakh: chicken, Azerbaijan: suçiçəyi.

sariğ käzik - jaundice (Abduvaliev et al., 2013a).

tumağu - flu, the common cold (Abduvaliev et al., 2013a). Turkmen: dümew; Kazakh: flu.

üçğuq - tuberculosis, influenza (Abduvaliev et al., 2013a).

\section{Names of Diseases in Dictionary with Other Names}

q1ruq - paralysis: quruq är - a paralyzed person (Abduvaliev et al., 2013a). Azerbaijan: paralysis, Kazakh: paralysis; Uzbek: paralysis; Tatar: paralysis.

Head ulcer: Head titik titti - ulcer caused severe pain (Abduvaliev et al., 2013a). Azerbaijan: wound; Kazakh: trauma; Turkemen: ýara; Uzbek: wound; Tater: ж⿻әрәхәт.

inägü - a pustule-like disease that occurs at the umbilical cord (Abduvaliev et al., 2013a);

bars - tumor, leprosy (name of the disease) (Abduvaliev et al., 2013a);

täşük - a hole, a hernia (Abduvaliev et al., 2013a). Currently, it is not used in the following:

sőgnägü - a sore on the nail (Abduvaliev et al., 2013a);

bağıriaq - bump (stripes) (Abduvaliev et al., 2013a);

atğaq - a disease in which adomen is filled with yellowish water (Abduvaliev et al., 2013a);

йамлығ көз - white eyes (Tokoev \& Koshmokov, 2011);

йупақулақ - fever, chills, chills, malaria (Tokoev \& Koshmokov, 2011). 


\section{Conclusion}

As a result of this study, dictionary by M. Kashkari "Divanu lugati t-turk" was examined on disease names used in the modern Kyrgyz language, and about their unchanged forms (öt - gallbladder, kőz - eye, baş - head, kirpik - eyelash, etc.), some of them are used with phonetic changes (buğın - joint, bőgőn - lump, ažaq - foot, foot, ämik - breast, ärnäk - toe, etc.) and some with other names (ožluq - bone marrow, kősri - chest, bağıriaq - rash, etc.). These are the facts that prove language as a social phenomenon. The results of this study showed that Kyrgyz language is one of the oldest Turkic languages. Research results obtained in this study can be used as a material for study of Turkic languages history and lexical content including modern Kyrgyz language.

Language is a social phenomenon developing with the progress in society. Some words become obsolete. New words are adopting from other language. M. Mashkari's dictionary "Divanu lugati t-turk" is a valuable material for historical study of the Turkic languages lexicon. Since the Kyrgyz language is also an ancient Turkic language, its modern vocabulary is studied in the article in order to determine extent relating to ancient time.

In particular, the results obtained from this article are useful as a material for comparative study of words in Turkic languages and their relationship with other words. With the development in society, the languages vocabulary has changed. In other words, research results can be used for determining the differences and commonalities, features in the lexicon of ancient and modern Turkic languages.

\section{Conflicts of Interest}

The authors declare no conflicts of interest regarding the publication of this paper.

\section{References}

Abduvaliev, I., Ahmatov, T., Omorov, A., Sultanaliev, I., \& Tolubaev, M. (2013a). Mahmut Kashkari. Divanu lugati-t turk. Turkish languages vocabulary. Part I, Bishkek: Biyiktik, 512 pages.

Abduvaliev, I., Ahmatov, T., Omorov, A., Sultanaliev, I., \& Tolubaev, M. (2013b). Mahmut Kashkari. Divanu lugati-t turk. Turkish languages vocabulary. Part II, Bishkek: Biyiktik, 304 pages.

Abduvaliev, I., Akhmataliev, T., Kadyrmambetova, A., Kasymgeldiev, M., Semenova, Z., Zhailoobaev, B., Isabekova A., Konurbaeva, R., Marazykov, T., Musaev, S., Olzhobaev, S., Osmonova, Z., Tolubaev, M., \& Shatmanov, T. (2011). Dictionary of the Kyrgyz language. Bishkek: Avrasya Press, 891 pages.

Davlatova, S. J. (2019). Advertising in the Dictionary of M. Kashgari "Divanu lugati at-tyurk" and Their Communication with Contemporary the Kyrgyz Language. ISJ Theoretical \& Applied Science, 3, 342-347. https://doi.org/10.15863/TAS.2019.03.71.21

Isabekova U. K. (2017). Linguistic personality of Mahmud Kashgari in the dialogue of cultures of the Middle Ages. Multilingualism and Transcultural Practices, 14, 423-430. https://doi.org/10.22363/2312-8011-2017-14-3-423-430

Isaeva, G. (2019). KIRGIZİSTAN'DA DİVANU LUGATİT TÜRK ARAŞTIRMALARI. 
Uluslararası Türk Dünyası Araștırmaları Dergisi, 2, 42-64.

Johanson, L., Csató, É. Á., \& Karakoç, B. (2020). Turkic Language Contacts. In R. Hickey (Ed.), The Handbook of Language Contact (pp. 551-570). Hoboken, NJ: John Wiley \& Sons Ltd.

Koshueva, M., Abduvalieva, E., Yzabekova, D., kyzy, B., Mamasadykov, A., Abduvaliev, I., \& Abdullaeva, Z. (2020). Phonetic Features of Sound-Copying Words Based on the Archival Materials. Open Journal of Modern Linguistics, 10, 665-674.

Malov, S.E. (1951). Monuments of Ancient Turkish Writing. Moscow, Leningrad: AN SSSR, 451 pages.

McCollum, A. G. (2020). Vowel Harmony and Positional Variation in Kyrgyz. Laboratory Phonology. Journal of the Association for Laboratory Phonology, 11, 25.

Musaev, S. (2016). The Kyrgyz Language. Problems of Modern Science and Education, 20, 56-58.

Nadelyaev, V. M., Nasilov, D. M., Tenishev, E. R., \& Shcherbak, A. M. (1969). Ancient Turkic Dictionary. Leningrad: Nauka, 676 pages.

Oruzbaeva, B. O. (2011). Mahmud Kashgar's Dictionary as a Source for Study of Vocabulary of the Kyrgyz Language in the Historical Plan (pp. 10-14). Bishkek: Mahmud Kashgari and Kyrgyz Culture.

Ragimov, A. R. (1985). "Divanu lugat-it-Turk” by Mahmud Kashgari and Azerbaijan Language Vocabulary (p. 25). Baku.

Tokoev, T., \& Koshmokov, K. (2011). Mahmoud Kashgari. Dictionary of Turkish Languages, Bishkek: Avrasya Press, 906 pages.

Usmambetov, B. Z. (2016). Mahmud Kashgari’s Dictionary “Divan lugat at Turk” and the Kyrgyz Language (Ethnolinguistic Analysis). Philological Sciences. Questions of Theory and Practice, 5-1, 154-156.

Yudakhin, K. K. (1985). Kyrgyz-Russian Dictionary. Moscow: Soviet Encyclopedia, Book 1: A to K. 503 pages; Book 2: L to I. 476 pages. 